\title{
Synthesis, Characterization and Catalytical Effects of Fe Contents on Pyrolysis of Cellulose with $\mathrm{Fe}_{2} \mathrm{O}_{3} / \mathrm{SBA}-15$ Catalysts
}

\author{
Agija STANKE ${ }^{1} *$, Valdis KAMPARS ${ }^{2}$, Kristine LAZDOVICA $^{3}$ \\ ${ }^{1-3}$ Riga Technical University, Institute of Applied Chemistry, Paula Valdena 3, Riga, Latvia
}

\begin{abstract}
In this study mesoporous SBA-15 was synthesized under acidic conditions using triblock copolymer Pluronic P123 as template and tetraethyl orthosilicate as a silica source. SBA-15 was modified by different iron loading $(1.8 \%, 5 \%$ and $10 \%)$ via post-synthesis impregnation with $\mathrm{Fe}\left(\mathrm{NO}_{3}\right)_{3} \cdot 9 \mathrm{H}_{2} \mathrm{O}$. The obtained catalysts were characterized using XRD analysis, WDXRF spectroscopy and $\mathrm{N}_{2}$ adsorption-desorption analysis. Pyrolysis of cellulose with and without the catalyst was investigated using TG-FTIR. It was found that the presence of the synthesized catalysts affects formation of solid residue and significantly alters the composition of the other pyrolysis products. All catalysts considerably reduced the fraction of compounds containing hydroxyl group. Fe (10\%)/SBA-15 exhibited the highest deoxygenation ability. SBA-15 showed the highest catalytic selectivity for synthesis of olefins, while $\mathrm{Fe}(1.8 \%) / \mathrm{SBA}-15$ showed the highest catalytic selectivity for synthesis of aromatic hydrocarbons.
\end{abstract}

Keywords - Bio-oil; catalytic pyrolysis; mesoporous SBA-15; TG-FTIR

\begin{tabular}{|ll}
\hline Nomenclature & \\
DTG & Derivative thermogravimetry \\
LGIR & Fourier transform infrared spectroscopy \\
SXRD & Levoglucosan \\
TG & Small-angle X-ray diffraction \\
WDXRF & Thermogravimetry \\
WXRD & Wavelength dispersive X-ray fluorescence \\
\hline
\end{tabular}

\section{INTRODUCTION}

Sustainable development is not possible without better use of renewable energy resources including biomass [1]. Bioresources are increasingly used in the production of high value-added products, in addition, as current trends continue, rapid development of biotechnologies is

\footnotetext{
* Corresponding author.

E-mail address: agija.stanke@rtu.lv

(C2020 Agija Stanke, Valdis Kampars, Kristine Lazdovica.

This is an open access article licensed under the Creative Commons Attribution License (http://creativecommons.org/ licenses/by/4.0), in the manner agreed with Sciendo.
} 
expected [2]. Bioresources and climate change, as key factors in the bioeconomy system, must be at the heart of political and strategic planning for the bioeconomy [3]. The EU wants to be a leader in reducing greenhouse gas emissions and plans to significantly change energy sources in the transport sector [4]. The implementation of renewable energy technologies requires a comprehensive energy policy and an appropriate government incentive [5].

Producing bio-oil, non-condensable gases and bio-coke, the pyrolysis remains one of the universal process of biomass conversion. Obtained products, especially the bio-oil, could be important feedstock for chemicals and transportation fuels. Unfortunately, crude bio oil also contains components such as water, aldehydes, acids and ketones which give it poor fuel performance. Catalytic pyrolysis is a promising way of reducing the oxygen content in bio-oil and improving its properties [6]-[8].

To achieve the desired effect different catalytic systems and classes of catalysts had been investigated. Of the various classes of catalysts great interest is caused by the supported mesoporous SBA-15 catalysts [9]. SBA-15 support distinguished by high thermal and hydrothermal stability, large surface area, hexagonally arranged mesopores and a thick pore wall [10]. Because SBA-15 contains only silica, it lacks active bonds and specific catalytic activity, but is considered as a very promising catalyst carrier [11], [12]. Catalyst consisting of metals or its oxides in form of nanoparticles can be easy affixed to the SBA-15. It is known that iron in form of $\mathrm{Fe}_{2} \mathrm{O}_{3}$ allows to obtain cheap and active supported SBA-15 catalysts [13], so we synthesized them and studied them in this work.

Depending on the origin lignocellulosic feedstock consists of hemicellulose, lignin and cellulose in different quantities that affects the distribution of final pyrolysis products [14]. In order to obtain selective information on the possibilities of catalytic pyrolysis of the main constituents, the present study investigated the pyrolysis of cellulose. Before us, cellulose pyrolysis predominantly has been studied using microporous zeolites and mesoporous MCM-41 [15].

\section{EXPERIMENTAL}

\subsection{Materials}

Pluronic P123, tetraethyl orthosilicate (TEOS), $\mathrm{HCl}$, ethanol, $\mathrm{Fe}\left(\mathrm{NO}_{3}\right)_{3} \cdot 9 \mathrm{H}_{2} \mathrm{O}$ were purchased from Sigma-Aldrich and used for synthesis of SBA-15 and Fe/SBA-15. All chemicals were analytical grade and used without further purification.

Microcrystalline cellulose powder (Sigma-Aldrich) was used for pyrolysis experiments as a model biomass.

\subsection{Synthesis of $S B A-15$}

SBA-15 was synthesized as reported by Zhao et al. [10]. $8 \mathrm{~g}$ of Pluronic P123 was dissolved in $30 \mathrm{~mL}$ of ethanol. Obtained solution of $P 123$ was added dropwise to $300 \mathrm{~mL}$ of $2.4 \mathrm{M} \mathrm{HCl}$ solution and stirred at $40{ }^{\circ} \mathrm{C}$ for $15 \mathrm{~min}$. Then $16 \mathrm{~g}$ of TEOS was added dropwise and the solution was stirred at $40^{\circ} \mathrm{C}$ for $2 \mathrm{~h}$ and then kept at $100^{\circ} \mathrm{C}$ for $72 \mathrm{~h}$ without stirring. The solid product was filtered, washed with distilled water, dried at $100{ }^{\circ} \mathrm{C}$ for $24 \mathrm{~h}$ and finally calcined in air at $550{ }^{\circ} \mathrm{C}$ for $5 \mathrm{~h}$. 


\subsection{Syntheses of $\mathrm{Fe} / \mathrm{SBA}-15$}

Fe/SBA-15 was generated by impregnating Fe precursor on calcinated SBA-15. Firstly, $0.50 \mathrm{~g}$ of $\mathrm{Fe}\left(\mathrm{NO}_{3}\right)_{3} \cdot 9 \mathrm{H}_{2} \mathrm{O}$ was dissolved in $70 \mathrm{~mL}$ of distilled water by stirring at room temperature. Adding $0.50 \mathrm{~g}$ of SBA-15, the solution was stirred at $50{ }^{\circ} \mathrm{C}$ for $1 \mathrm{~h}$. Then, precipitate was filtrated and dried at $100{ }^{\circ} \mathrm{C}$ for $24 \mathrm{~h}$. Finally, calcination was conducted at $550{ }^{\circ} \mathrm{C}$ for $5 \mathrm{~h}$ in air. Using WDXRFS method, it was determined that this catalyst contains $1.8 \%$ iron and catalyst was denoted as $\mathrm{Fe}(1.8 \%) / \mathrm{SBA}-15$.

Impregnated mesoporous materials Fe (5\%)/SBA-15 and Fe (10\%)/SBA-15 were prepared as follows: the amount of $\mathrm{Fe}\left(\mathrm{NO}_{3}\right)_{3} \cdot 9 \mathrm{H}_{2} \mathrm{O}$ dissolved in $80 \mathrm{~mL}$ of distilled water was added to $1 \mathrm{~g}$ of SBA-15, the obtained mixture was stirred at $50{ }^{\circ} \mathrm{C}$ for $3 \mathrm{~h}$. Water was evaporated and the solid was dried at $100{ }^{\circ} \mathrm{C}$ for $24 \mathrm{~h}$. Finally, calcination was conducted at $550{ }^{\circ} \mathrm{C}$ for $5 \mathrm{~h}$ in the air.

\subsection{Cellulose Characterization}

Table 1 shows the main characteristics of cellulose: proximate, ultimate analysis and higher heating value (HHV).

The HHV was estimated according to procedures of CEN/TS 14918, by bomb calorimetry (IKA Calorimeter system C200).

Proximate analysis of cellulose included the determination of volatile matter, fixed carbon and ash content. These parameters were obtained according to CEN/TS 15148 and CEN/TS 14775 standard procedures using TG analyser (PerkinElmer STA 6000) and muffle furnace (Nabertherm HTC 03/16).

The carbon, hydrogen, nitrogen and sulphur concentrations (weight percent) of cellulose was determined in Euro Vector EA 3000 elemental analyser, where sample was combusted in pure oxygen environment at $980{ }^{\circ} \mathrm{C}$. The amount of oxygen was calculated by the difference:

$$
\mathrm{O}(w t . \%)=100 \%-(\mathrm{C} \%+\mathrm{H} \%+\mathrm{N} \%+\mathrm{S} \%)-\mathrm{Ash} \%,
$$

where $\mathrm{C} \%, \mathrm{H} \%, \mathrm{~N} \%, \mathrm{~S} \%$, Ash $\%$ are weight percents of carbon, hydrogen, nitrogen, sulphur and ash.

Table 1. The Proximate, Ultimate and HHV of Cellulose

\begin{tabular}{lclc}
\hline \multicolumn{2}{c}{ Proximate analysis, wt.\% } & \multicolumn{2}{c}{ Ultimate analysis, wt.\% } \\
\hline Volatile matter & 92.67 & Carbon & 44.15 \\
Fixed Carbon & 6.62 & Hydrogen & 6.29 \\
Ash content & 0.71 & Nitrogen & 0.16 \\
& & Sulphur & 0.00 \\
$\mathrm{HHV}, \mathrm{J} / \mathrm{g}$ & 17153 & Oxygen & 48.69 \\
\hline
\end{tabular}

\subsection{Catalyst Characterization}

The crystal structure was analysed by X-ray diffractometer (D8 ADVANCE Bruker AXS GmbH) using $40 \mathrm{kV}, 40 \mathrm{~mA} \mathrm{Cu} \mathrm{K \alpha} \mathrm{X}$-ray. The XRD patterns were obtained within the scan range of $2 \Theta=0.5^{\circ}$ to $2^{\circ}$ with the step size of $0.01^{\circ}$ and within the scan range of $2 \Theta=2^{\circ}$ to $50^{\circ}$ with the step size of $0.02^{\circ}$.

Iron concentration was determined using a Rigaku Supermini wavelength x-ray dispersive fluorescence spectrometer (WDXRFS) with a Rh X-ray tube. 
$2020 / 24$

The surface area and the pore size were determined by $\mathrm{N}_{2}$ adsorption-desorption isotherms obtained at $-196{ }^{\circ} \mathrm{C}$ on Quantachrome Instruments Nova 1200 E-Series surface and porosity analyser. The samples were out-gassed at $273{ }^{\circ} \mathrm{C}$ for $4 \mathrm{~h}$ prior to adsorption. Total surface area was estimated using the Brunauer-Emmett-Teller (BET) method. Pore width distributions were derived from desorption isotherms using the Barrett-Joyner-Halenda $(\mathrm{BJH})$ method.

\subsection{Catalytic Tests}

To investigate the mass loss of cellulose and formation of volatile products at the same time the pyrolysis experiments were performed using Perkin Elmer STA 6000 Simulaneous Thermal Analyzer coupled to the Fourier transform infra-red spectrometer (FTIR spectrometer PerkinElmer Spectrum 100) by a transfer line (TL8000).

To ensure the precision of the cellulose thermogravimetric experiment results, the thermal stability of the catalysts was tested in the TG before catalytic pyrolysis of cellulose. Almost no weight loss was observed during heating above $300{ }^{\circ} \mathrm{C}$, indicating that SBA-15, Fe $(1.8 \%) / \mathrm{SBA}-$ $15, \mathrm{Fe}(5 \%) / \mathrm{SBA}-15$ and $\mathrm{Fe}(10 \%) / \mathrm{SBA}-15$ had good thermostability. Weigh loss below $300{ }^{\circ} \mathrm{C}$ was due to moisture content.

Before catalytic tests, cellulose and sand was dried at $100{ }^{\circ} \mathrm{C}$ for $5 \mathrm{~h}$, and catalysts were dried at $300{ }^{\circ} \mathrm{C}$ for $2 \mathrm{~h} .32 \mathrm{mg}$ of cellulose was mixed directly with $32 \mathrm{mg}$ of catalyst and placed in the sample cup. To ensure equal mass-transition process for non-catalytic process, mixture of $32 \mathrm{mg}$ of cellulose with $32 \mathrm{mg}$ of inert quartz sand was used. Samples were heated from $30{ }^{\circ} \mathrm{C}$ to $700{ }^{\circ} \mathrm{C}$ at heating rate of $100{ }^{\circ} \mathrm{C} / \mathrm{min}$ under inert atmosphere. Nitrogen gas at a flow rate of $20 \mathrm{ml} / \mathrm{min}$ was used as the carrier gas flowing through the pyrolyzer. Volatile products of cellulose intermediate pyrolysis were analysed by FTIR spectroscopy. FTIR spectrum were recorded every $9 \mathrm{~s}$, the scanning range was between $4000 \mathrm{~cm}^{-1}$ and $650 \mathrm{~cm}^{-1}$ with resolution factor of $4 \mathrm{~cm}^{-1}$. All transfer lines connecting reactor with the spectrometer were heated to $280{ }^{\circ} \mathrm{C}$ to avoid product condensation. The characteristic absorptions of the functional groups used to determine formation of certain volatile compounds in cellulose pyrolysis process are listed in Table 2.

TABle 2. THE CHARACTERISTIC ABSORPTIONS OF THE VOLATILES USED TO ASCERTAIN THEIR FORMATIONS IN CELLULOSE PYROLYSIS PROCESS

\begin{tabular}{lllll}
\hline Reference & Absorption band, $\mathbf{c m}^{\mathbf{- 1}}$ & Peak, $\mathbf{c m}^{-\mathbf{1}}$ & Assignment & Compounds \\
\hline $2217-2391$ & 2309 & $v_{\mathrm{as}} \mathrm{C}=\mathrm{O}$ & $\mathrm{CO}_{2}$ \\
& $2071-2207$ & 2182 & $v \mathrm{C}-\mathrm{O}$ & $\mathrm{CO}$ \\
$2972-3018$ & 3014 & $v \mathrm{C}-\mathrm{H}$ & $\mathrm{CH}_{4}$ \\
& $1690-1800$ & 1797 & $v \mathrm{C}=\mathrm{O}$ & Acids \\
& $1700-1740$ & 1738 & $v \mathrm{C}=\mathrm{O}$ & Ketones \\
{$[16]$} & 2812 & $v \mathrm{C}-\mathrm{H}(\mathrm{H}-\mathrm{C}=\mathrm{O})$ & Aldehydes \\
& $2770-2860,1684-1745$ & 1064 & $v \mathrm{C}-\mathrm{O}-\mathrm{H}$ & Alcohols, anhydrosugars \\
& $3585-3650,1058-1131$ & 1183 & $v_{\text {as }} \mathrm{C}-\mathrm{O}-\mathrm{C}$ & Levoglycosan \\
& $1100-1200$ & 3950 & $v \mathrm{O}-\mathrm{H}$ & $\mathrm{H}_{2} \mathrm{O}$ \\
& $3600-4000$ & 950 & $\gamma=\mathrm{CH}$ & Olefins \\
& $950-993,900-920$ (vinyl) & 740 & $\gamma \mathrm{C}-\mathrm{H}$ & Aromatics \\
\hline $650-900,728-770$ (phenyl) & & $\gamma-0 \mathrm{of}$ &
\end{tabular}

Note: $v-$ stretching vibrations; $v_{\mathrm{AS}}-$ asymmetric stretching vibrations; $\gamma$ - out of plane bending 
Solid residue of cellulose formed in pyrolysis process was calculated based on the mass change during TG analysis:

$$
\text { Solid residue of cellulose }(\%)=\frac{m_{\mathrm{end}}-m_{\mathrm{cat}}}{m_{\mathrm{start}}-m_{\mathrm{cat}}} 100 \% \text {, }
$$

where

$$
\begin{array}{ll}
m_{\text {end }} & \text { mass of the sample at the end of pyrolysis; } \\
m_{\text {cat }} & \text { mass of the catalyst; } \\
m_{\text {start }} & \text { mass of the sample at the start of pyrolysis. }
\end{array}
$$

The evaluation of volatile products was analysed during pyrolysis. Absorption spectra profile for each volatile substance (intensity of designated regions of spectra) was obtained with the respect to time/temperature. The relative yield for each compound were assumed as an integral intensity of absorbance-temperature curve (2D curve) calculated according to [16]:

$$
S=\sum_{n=30}^{n=\text { final temperature }}=0.5\left(A_{n}+A_{n-1}\right)\left(T_{n}-T_{n-1}\right),
$$

where

$S \quad$ integral intensity of absorbance and temperature (2D curve) or relative yield;

$T_{n}, T_{n-1} \quad$ experimental temperatures;

$A_{n}, A_{n-1} \quad$ absorbance at specific wavenumber at temperatures $T_{n}$ and $T_{n-1}$.

This study focused only on the composition of volatile compounds; the composition of char and coke were not investigated.

\section{RESUltS AND DisCUSSION}

\subsection{XRD Characterization}

According to the literature, the calcination of iron nitrate at a temperature beyond $500{ }^{\circ} \mathrm{C}$ resulted predominantly the $\alpha-\mathrm{Fe}_{2} \mathrm{O}_{3}$ (hematite) [17]-[19]. The wide angle XRD pattern (Fig. 1B) of SBA-15 showed its characteristic peak at $2 \Theta=15^{\circ}-35^{\circ}$ due to amorphous $\mathrm{SiO}_{2}$. For Fe $(1.8 \%) / S B A-15, \mathrm{Fe}(5 \%) / \mathrm{SBA}-15$ and $\mathrm{Fe}(10 \%) / \mathrm{SBA}-15$ the WXRD patterns were similar to that of SBA-15 and only presented the peak of amorphous silica, which was presumably because $\mathrm{Fe}_{2} \mathrm{O}_{3}$ did not exist in crystalline form or because the cluster size of nano- $\mathrm{Fe}_{2} \mathrm{O}_{3}$ was smaller than the detection limit by X-ray. Small angle XRD peaks of Fe/SBA-15 shifted toward lower angles as the Fe loading increases (Fig. 1A) because the unit cell parameter of SBA-15 became smaller (Table 3).

Fig. 1A shows the small angle XRD diffraction patterns of the catalysts. The small angle XRD patterns of all synthesized catalysts exhibited a (100), (110), and (200) diffraction peak representing 2D p6 mm hexagonal mesoporous structure. The $\mathrm{Fe}_{2} \mathrm{O}_{3}$ loaded mesoporous silica showed no obvious alteration, which proved that the modification and the loading of $\mathrm{Fe}_{2} \mathrm{O}_{3}$ did not alter the mesostructure and orderliness of SBA-15. However, the relative intensity of (100) plane decreased with the increment of Fe concentration. This intensity loss indicates that too high an iron content is detrimental to the quality of the SBA-15 materials. This might be due to the lattice disorder and strain induced by interstitial Fe atoms. 

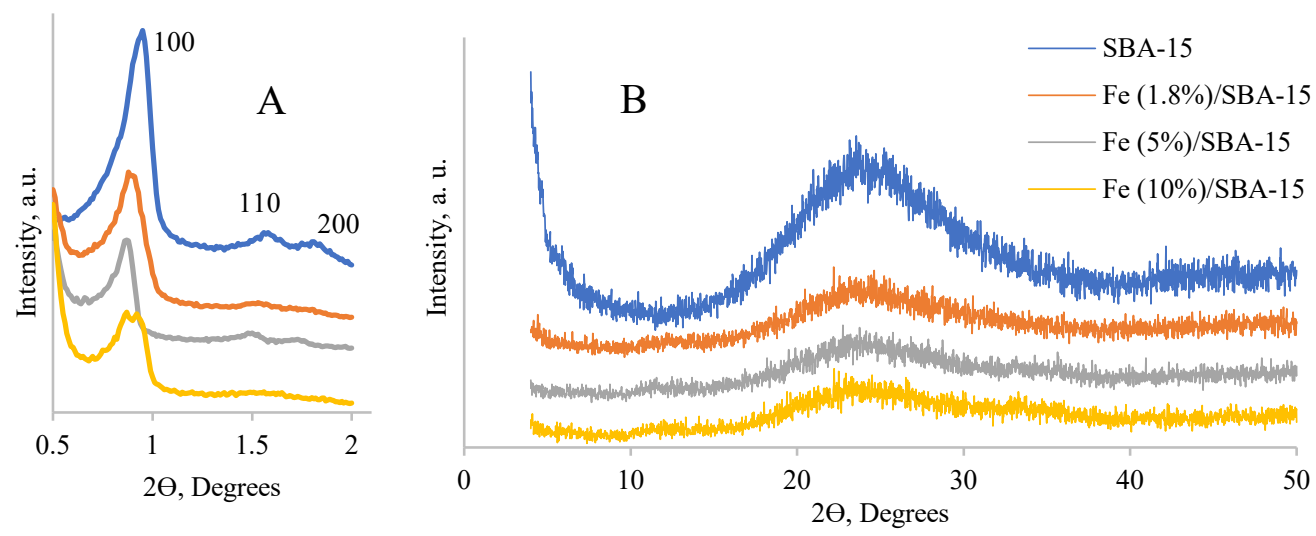

Fig. 1. SXRD (A) and WXRD (B) patterns of SBA-15, Fe (1.8\%)/SBA-15, Fe (5\%)/SBA-15, Fe (10 \%)/SBA-15.

\section{2. $N_{2}$ Sorption Analysis}

The $\mathrm{N}_{2}$ adsorption-desorption isotherms and corresponding BJH pore size distribution of the SBA-15 and Fe (\%)/SBA-15 materials are shown in Fig. 2. The nitrogen physisorption isotherms of the catalysts corresponded to typical IUPAC type IV with H1 hysteresis loop [20] with the capillary condensation step supporting that SBA-15, Fe (1.8\%)/SBA-15, Fe (5\%)/SBA-15 and $\mathrm{Fe}(10 \%) / \mathrm{SBA}-15$ are mesoporous in nature. Impregnation with $\mathrm{Fe}_{2} \mathrm{O}_{3}$ does not change the mesoporous structure of the catalysts.

BET surface areas, pore volumes, pore diameters and pore wall thicknesses are presented in Table 3. It clearly shows that the surface area and total pore value slightly decreased whereas wall thickness increased upon substitution with $\mathrm{Fe}_{2} \mathrm{O}_{3}$.

TABle 3. Structural Properties OF $\mathrm{FE}_{2} \mathrm{O}_{3} / \mathrm{SBA}-15$

\begin{tabular}{|c|c|c|c|c|c|c|}
\hline Catalyst & $\begin{array}{c}\text { d-spacing } \\
\text { nm }\end{array}$ & $\mathbf{a}_{0}{ }^{b}, \mathbf{n m}$ & $\begin{array}{c}\text { BET surface } \\
\text { area, } \mathrm{m}^{2} / \mathrm{g}\end{array}$ & $D_{\text {pore }}^{c}, \mathbf{n m}$ & $V_{\text {total }}{ }^{\mathrm{d}}, \mathrm{cm}^{3} / \mathrm{g}$ & $\begin{array}{c}\text { Wall } \\
\text { thickness }{ }^{\mathrm{e}}, \mathrm{nm}\end{array}$ \\
\hline SBA-15 & 9.30 & 10.7 & 849.5 & 6.52 & 1.38 & 3,88 \\
\hline $\mathrm{Fe}(1.8 \%) / \mathrm{SBA}-15$ & 9.82 & 11.3 & 732.6 & 6.38 & 1.17 & 4,38 \\
\hline $\mathrm{Fe}(5 \%) / \mathrm{SBA}-15$ & 10.15 & 11.7 & 665.1 & 7.11 & 1.18 & 4,80 \\
\hline $\mathrm{Fe}(10 \%) / \mathrm{SBA}-15$ & 10.15 & 11.7 & 613.8 & 6.20 & 0.95 & 6,16 \\
\hline
\end{tabular}

${ }^{a}$ The d-spacing based on (100) plane was calculated from $n \lambda=2 d_{100} \sin \Theta$

${ }^{b}$ The unit cell parameters were calculated from low angle XRD patterns using $\mathrm{a}_{0}=2 \mathrm{~d}_{100} / \sqrt{3}$

${ }^{\mathrm{c}}$ Pore diameters were derived from the desorption branches of the isotherms by using BJH method

${ }^{d}$ Total pore volumes estimated from the absorbed amount at a relative pressure of $\mathrm{p} / \mathrm{p}_{\mathrm{o}}=0.99$

${ }^{\mathrm{e}}$ Wall thickness was calculated from Wall thickness $=\mathrm{a}_{\mathrm{o}}-\mathrm{D}_{\text {pore }}$

Pore size distribution curve (Fig. 2B) indicates mesopores, with the diameter from about $5 \mathrm{~nm}$ to $8 \mathrm{~nm}$. Pore size decreases with increased loading of $\mathrm{Fe}_{2} \mathrm{O}_{3}$ nanoparticles for all synthesized catalysts. Narrow pore size distribution confirms that highly dispersed $\mathrm{Fe}_{2} \mathrm{O}_{3}$ nanoparticles does not disrupt the porous hexagonal structure of the support [21]. 

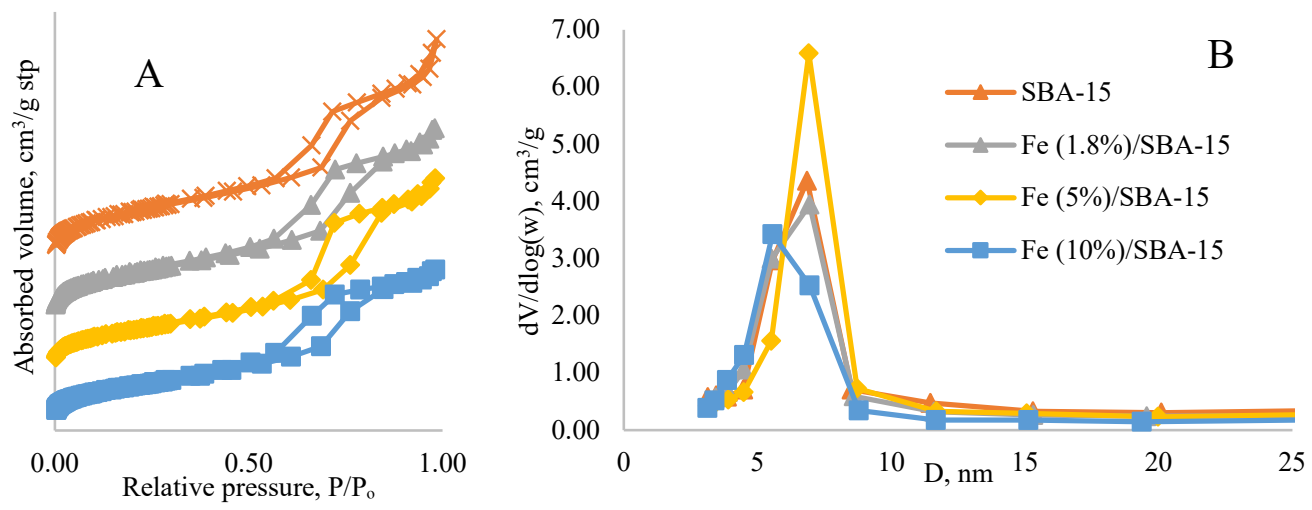

Fig. 2. $\mathrm{N}_{2}$ physisorption isotherm (A) and pore size distribution (B) of SBA-15, Fe (1.8\%)/SBA-15, Fe (5\%)/SBA-15, $\mathrm{Fe}(10 \%) / \mathrm{SBA}-15$.

\subsection{Catalytic Activity}

Fig. 3 shows the TG and DTG curves for cellulose in catalytic and non-catalytic conditions. The thermal degradation of cellulose with quartz sand (non-catalytic) and catalysts occurred in three major weight loss steps. The first weight loss step occurred between $30^{\circ} \mathrm{C}$ and $210{ }^{\circ} \mathrm{C}$; it was due to evaporation of moisture and formation of the anhydrocellulose. The main weight loss step occurred at temperature range from $300{ }^{\circ} \mathrm{C}$ to $500{ }^{\circ} \mathrm{C}$. This step can be assigned to a series of reactions involving dehydration, decarboxylation, decarbonylation, fragmentation, and rearrangement. The final weight loss step was observed at the temperature range from $430{ }^{\circ} \mathrm{C}$ to $650^{\circ} \mathrm{C}$; this step corresponds to the charring of the residue [6], [22].

Table 4 presents the characteristic points of the TG (Fig. 3A) and DTG (Fig. 3B) curves. The presence of catalysts resulted in the delay of the start point of the major weight-loss stage $\left(\mathrm{T}^{\mathrm{a}}\right.$, Table 4), this could be due to porous structure of the catalysts. The final temperature was increased by $118{ }^{\circ} \mathrm{C}$ with the addition of SBA-15 and decreased by about $20^{\circ} \mathrm{C}$ with the addition of iron oxide loaded catalysts. It indicates that Fe/SBA-15 may decrease pyrolysis time, while SBA-15 prolongs pyrolysis time.

The derivative weight loss $(\mathrm{d} w / \mathrm{d} T)$ can be expressed as $\frac{\mathrm{d} w}{\mathrm{~d} t}=\left(\frac{\mathrm{d} w}{\mathrm{~d} T}\right)\left(\frac{\mathrm{d} T}{\mathrm{~d} t}\right)$, and as in our experiments we had constant heating rate $(\mathrm{d} T / \mathrm{d} t)$, the derivative peaks of the thermogram reflect a kinetic rate of degradation [23]. Comparing derivative weight loss peaks of catalytic processes with non-catalytic process (Fig. 3B), it can be seen that the presence of SBA-15 resulted in a decrease in the $(\mathrm{d} w / \mathrm{d} t)_{\max }$ suggesting that SBA-15 has lowered the rate of thermal degradation of cellulose. In contrast presence of Fe/SBA-15 resulted in an increase in the $(\mathrm{d} w / \mathrm{d} t)_{\max }$, besides as more $\mathrm{Fe}_{2} \mathrm{O}_{3}$ contains the catalysts as more increased $(\mathrm{d} w / \mathrm{d} t)_{\max }$ suggesting that thermal degradation of cellulose in presence of $\mathrm{Fe}(10 \%) / \mathrm{SBA}-15$ has a highest rate of thermal degradation. 

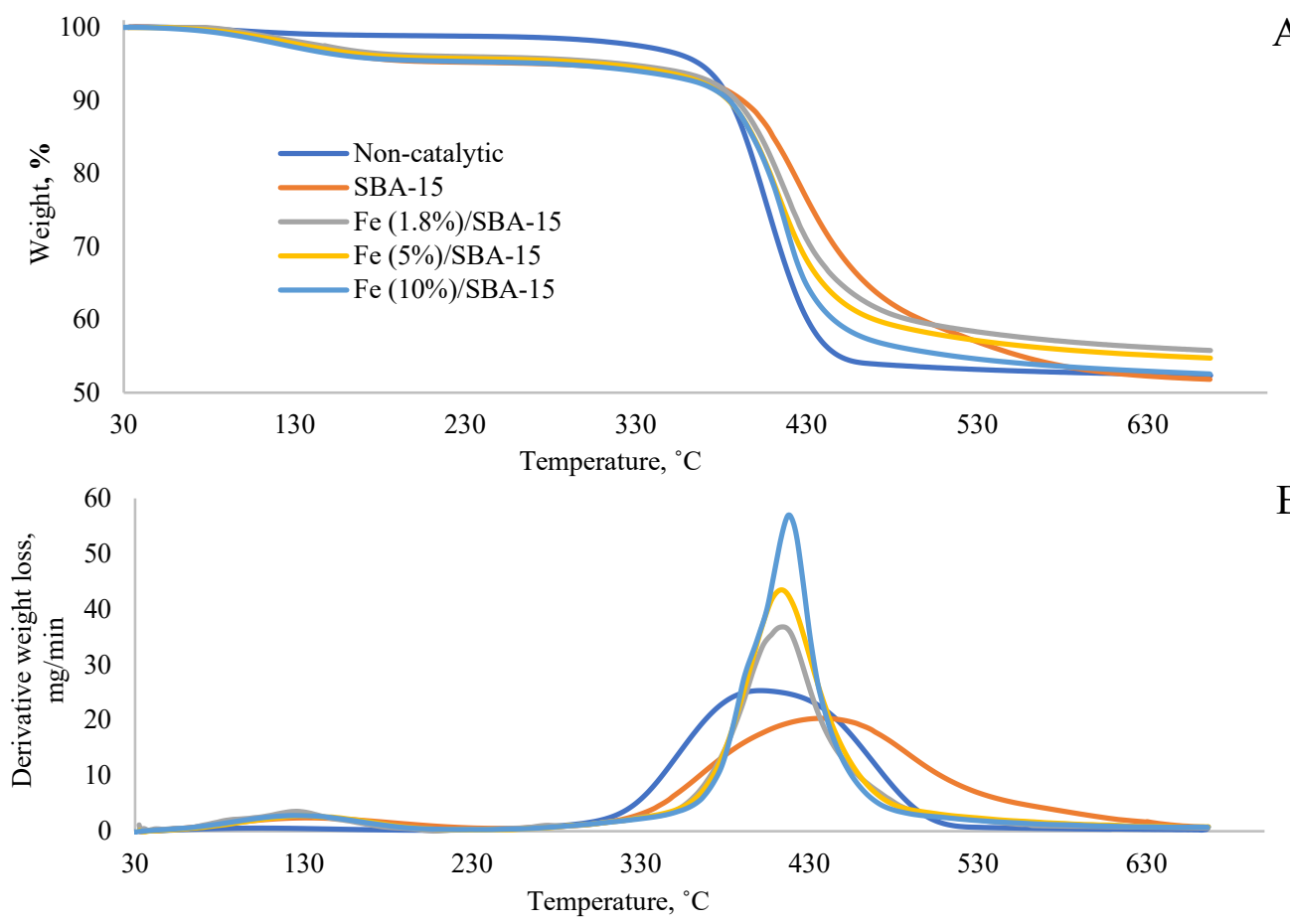

Fig. 3. TG (A) and DTG (B) curves for cellulose in catalytic and non-catalytic conditions.

The formation of solid residue was increased by the iron oxide loading. Residual yield ( $\mathrm{W}^{\mathrm{d}}$, Table 4) showed the following decreasing order of Fe $(1.8 \%) / \mathrm{SBA}-15>\mathrm{Fe}(5 \%) / \mathrm{SBA}-15>$ Fe $(10 \%) / \mathrm{SBA}-15>$ non-catalytic $>$ SBA-15 thus we can assume that formation of solid residue is impacted by both catalyst surface area and iron content. The increase of solid residue most likely is related to coke formation.

TABle 4. The Characteristic Points of the TG AND DTG Curves

\begin{tabular}{lccccc}
\hline & $\mathbf{T}^{\mathbf{a}},{ }^{\circ} \mathbf{C}$ & $\mathbf{T}^{\mathbf{b}},{ }^{\circ} \mathbf{C}$ & $\mathbf{T}^{\mathbf{c}},{ }^{\circ} \mathbf{C}$ & $(\mathbf{d} \boldsymbol{w} / \mathbf{d} \boldsymbol{t})_{\mathbf{m a x}}, \mathbf{m g} / \mathbf{m i n}$ & $\mathbf{W}^{\mathbf{d}}, \mathbf{\%}$ \\
\hline Non-catalytic & 298 & 400 & 514 & 25.35 & 4.76 \\
SBA-15 & 312 & 437 & 632 & 20.35 & 3.66 \\
Fe (1.8 \%)/SBA-15 & 321 & 414 & 497 & 36.84 & 11.57 \\
Fe (5 \%)/SBA-15 & 327 & 413 & 491 & 43.51 & 9.47 \\
Fe (10 \%)/SBA-15 & 339 & 418 & 490 & 56.97 & 5.13 \\
\hline
\end{tabular}

${ }^{\text {a }}$ Start of major weight-loss stage (change of DTG tends to be greater than $0.05 \mathrm{mg} / \mathrm{min}$ )

${ }^{\mathrm{b}}$ Peak point of the DTG curve

${ }^{\mathrm{c}}$ End of major weight-loss stage (change of DTG tends to be smaller than $0.05 \mathrm{mg} / \mathrm{min}$ )

${ }^{\mathrm{d}}$ Solid residue of the cellulose at the end of pyrolysis

Fig. 4 shows relative changes of cellulose pyrolysis products yields compared to non-catalytic pyrolysis product yields. 
For catalytic pyrolysis of cellulose, the relative yield of alcohols, levoglycosan and other anhydrosugars were reduced considerably. Among the four catalysts, the Fe $(10 \%) / \mathrm{SBA}-15$ catalyst displayed the best activity in reducing the oxygenated compounds. Olefins, which were undetectable in the non-catalytic pyrolysis, were produced. The yield of mono-substituted aromatic hydrocarbons increased considerably. This change is attributed to the conversion of oxygenates to other species though deoxygenation reactions, such as dehydration, decarboxylation, and decarbonylation. (Note: The operating conditions of the transfer lines between pyrolizer and FTIR cannot completely exclude the possibility of condensation of polycyclic aromatic hydrocarbons and heavy compounds.)

As it can be seen from Fig. 4, all the catalysts increased olefin yield, but the catalytic activities were gradually inhibited with the increase of Fe content. We can assume that formation of olefins is affected mainly by catalyst porosity and surface area.

It is known that aromatics and coke production are both functions of catalyst acidity, shape selectivity and pore size [24]. As it can be seen from Table 4 and Fig. 4, weight of solid residue and mono-substituted aromatic hydrocarbon yield increases in following order: SBA-15 < $\mathrm{Fe}(10 \%) / \mathrm{SBA}-15<\mathrm{Fe}(5 \%) / \mathrm{SBA}-15<\mathrm{Fe}(1.8 \%) / \mathrm{SBA}-15$. In our case, supported iron oxide system provides active sites however, increased iron content leads to decrease of catalyst surface area and pore size.

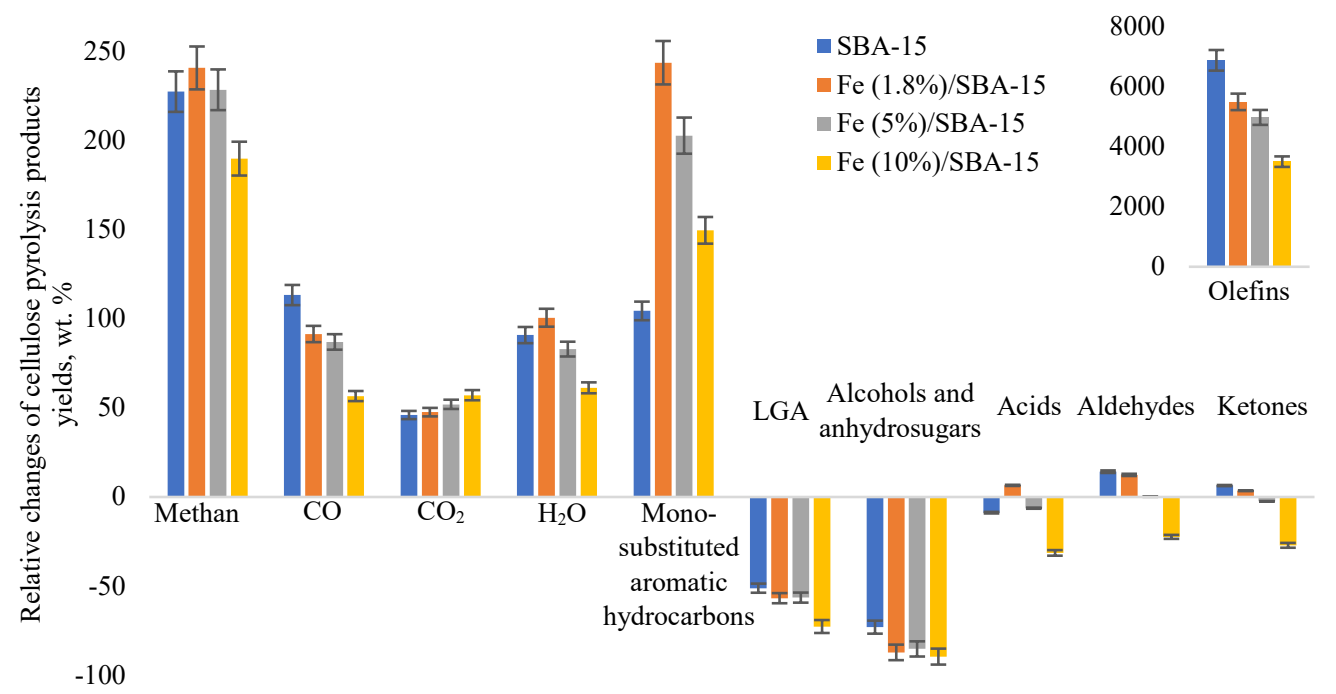

Fig. 4. Relative changes of catalytic cellulose pyrolysis products yields compared to non-catalytic pyrolysis product yields.

\section{Conclusions}

The SBA-15 and Fe/SBA-15 with Fe $=1.8 \%, 5 \%$ and $10 \%$ were prepared, characterized and applied for catalytic pyrolysis of cellulose. The characterization techniques showed that ordered structure of SBA-15 remained after the incorporation of iron.

Results of catalytic tests showed that catalyst surface area and iron content affect the formation of solid residue. The highest rate of thermal degradation of cellulose was in presence of 
$\mathrm{Fe}(10 \%) / \mathrm{SBA}-15$. The addition of $\mathrm{Fe}_{2} \mathrm{O}_{3}$ increased the yield of high-value-added compounds by promoting cracking, dehydrogenation, and aromatization. Fe (10\%)/SBA-15 showed the best deoxygenation performance, reducing relative yields of alcohols, levoglucosan (LGA) and other anhydrosugars, acids, aldehydes, ketones. Formation of mono-substituted aromatic hydrocarbons the most was promoted by $\mathrm{Fe}(1.8 \%) / \mathrm{SBA}-15$.

\section{ACKNOWLEDGEMENT}

This research is funded by the Ministry of Economics of the Republic of Latvia, project VPP-2018-ENERGY, project No. VPP-EM-AER-2018/3-0004.

\section{REFERENCES}

[1] Ghatak H. R. Biorefineries from the perspective of sustainability: Feedstocks, products, and processes. Renewable and Sustainable Energy Reviews 2011:15(8):4042-4052. https://doi.org/10.1016/j.rser.2011.07.034

[2] Lauka D., et al. When Bioeconomy Development Becomes a Biomass Energy Competitor. Environmental and Climate Technologies 2019:23(3):347-359. https://doi.org/10.2478/rtuect-2019-0100

[3] Indzere Z., Melvere M., Muizniece I., Blumberga D. The Evaluation of Factors Affecting Bioeconomy Development Using Transdisciplinary Approach. Environmental and Climate Technologies 2019:23(3):360-369. https://doi.org/10.2478/rtuect-2019-0101

[4] Directive 2018/2001/EU of the European Parliament and of the Council of 11 December 2018 on the promotion of the use of energy from renewable sources. Official Journal of the European Union 2018:328:82-209.

[5] Suharevska K., Blumberga D. Progress in Renewable Energy Technologies: Innovation Potential in Latvia. Environmental and Climate Technologies 2019:23(2):47-63. https://doi.org/10.2478/rtuect-2019-0054

[6] Collard F. X., Blin J. A review on pyrolysis of biomass constituents: Mechanisms and composition of the products obtained from the conversion of cellulose, hemicelluloses and lignin. Renewable and Sustainable Energy Reviews 2014:38:594-608. https://doi.org/10.1016/j.rser.2014.06.013

[7] Jeon M. J., et al. Catalytic pyrolysis of waste rice husk over mesoporous materials. Nanoscale Research Letters 2012:7:18. https://doi.org/10.1186/1556-276X-7-18

[8] Tan S., et al. Catalysts in Biomass Pyrolysis: A Brief Review. Advanced Materials Research 2012:608:428-432. https://doi.org/10.4028/www.scientific.net/AMR.608-609.428

[9] Bridgwater A. V. Review of fast pyrolysis of biomass and product upgrading. Biomass and Bioenergy 2012:38:6894. https://doi.org/10.1016/j.biombioe.2011.01.048

[10] Zhao D., et al. Triblock Copolymer Syntheses of Mesoporous Silica with Periodic 50 to 300 Angstrom Pores. Science 1998:279:548-552.

[11] Zhang Y., et al. Catalytic Pyrolysis of Biomass with Fe/La/SBA-15 Catalyst using TGA - FTIR Analysis. BioResources 2014:9(3):5234-5245. https://dx.doi.org/10.15376/biores.9.3.5234-5245

[12] Sun Y., et al. Highly dispersed iron oxide nanoclusters supported on ordered mesoporous SBA-15: A very active catalyst for Friedel - Crafts alkylations. Applied Catalysis A: General 2006:300(1):1-7. https://doi.org/10.1016/j.apcata.2005.10.029

[13] Li C., et al. Catalytic Fast Pyrolysis of Forestry Wood Waste for Bio-Energy Recovery Using Nano-Catalysts. Energies 2019:12(20):3972. https://doi.org/10.3390/en12203972

[14] Huang Y. F., et al. Pyrolysis of biomass by thermal analysis-mass spectrometry (TA-MS). Bioresource Technology 2011:102(3):3527-3534. https://doi.org/10.1016/j.biortech.2010.11.049

[15] Jeon M. J., et al. Catalytic pyrolysis of biomass components over mesoporous catalysts using Py-GC/MS. Catalysis Today 2013:204:170-178. https://doi.org/10.1016/j.cattod.2012.07.039

[16] Lazdovica K., Kampars V., Liepina L., Vilka M. Comparative study on thermal pyrolysis of buckwheat and wheat straws by using TGA-FTIR and Py-GC/MS methods. Journal of Analytical and Applied Pyrolysis 2017:124:1-15. https://doi.org/10.1016/j.jaap.2017.03.010

[17] Bora D. K., et al. Evolution of structural properties of iron oxide nano particles during temperature treatment from $250{ }^{\circ} \mathrm{C}-900^{\circ} \mathrm{C}$ : X-ray diffraction and Fe K-shell pre-edge X-ray absorption study. Current Applied Physics 2012:12(3):817-825. https://doi.org/10.1016/j.cap.2011.11.013

[18] Farahmandjou M., Soflaee F. Synthesis and characterization of $\alpha-\mathrm{Fe}_{2} \mathrm{O}_{3}$ nanoparticles by simple co-precipitation method. Physical Chemistry Research 2015:3:191-196. https://dx.doi.org/10.22036/pcr.2015.9193 
[19] Joya M. R., Baron-Jaimez J., Barba-Ortega J. Preparation and characterization of $\mathrm{Fe}_{2} \mathrm{O}_{3}$ nanoparticles. Journal of Physics: Conference Series, 466. https://doi.org/10.1088/1742-6596/466/1/012004

[20] Sing K. S. W., et al. Reporting Physisorption Data for Gas/Solid Systems with Special Reference to the Determination of Surface Area and Porosity. Pure and Applied Chemistry 1985:57:603-619. https://doi.org/10.1351/pac198557040603

[21] Baharudin K. B., et al. Mesoporous NiO/Al-SBA-15 catalysts for solvent-free deoxygenation of palm fatty acid distillate. Microporous and Mesoporous Materials 2019:276:13-22. https://doi.org/10.1016/j.micromeso.2018.09.014

[22] Yang H., et al. Characteristics of hemicellulose, cellulose and lignin pyrolysis. Fuel 2007:86(12-13):1781-1788 https://doi.org/10.1016/j.fuel.2006.12.013

[23] Maddi B., Viamajala S., Varanasi S. Comparative study of pyrolysis of algal biomass from natural lake blooms with lignocellulosic biomass. Bioresource Technology 2011:102(23):11018-11026. https://doi.org/10.1016/j.biortech.2011.09.055

[24] Kelkar S., et al. A survey of catalysts for aromatics from fast pyrolysis of biomass. Applied Catalysis B: Environmental 2015:174-175:85-95. https://doi.org/10.1016/j.apcatb.2015.02.020 